\title{
Urban Sprawl di Indonesia dan Kegagalan Implementasi Kebijakan Perlindungan Lahan Pertanian Pangan Berkelanjutan
}

\author{
Arsan Nurrokhman \\ Pusat Penelitian dan Pengembangan \\ Kementerian Agraria dan Tata Ruang/Badan Pertanahan Nasional \\ arsannur@gmail.com
}

\begin{abstract}
Abstrak
Tujuan penelitian ini adalah menganalisis fenomena penjalaran kota (urban sprawl) di Indonesia dan implementasi kebijakan perlindungan lahan pertanian pangan. Penelitian menemukan bahwa urban sprawl cenderung diabaikan sebagai konteks besar implementasi kebijakan Undang-Undang Nomor 41 Tahun 2009 tentang Perlindungan Lahan Pertanian Pangan Berkelanjutan. Antisipasi atas masalah alih fungsi lahan menjadi bersifat sektoral, terbatas dalam sektor pertanian saja, tidak terhubung dengan kebijakan lain seperti penyediaan perumahan dan pembatasan kendaraan bermotor, sehingga undang-undang tersebut gagal diimplementasikan.
\end{abstract}

Kata kunci: urban sprawl, alih fungsi lahan pertanian

\begin{abstract}
The purpose of this study was to analyze the phenomenon of urban sprawl in Indonesia and the implementation of food crop protection policies. The study found that urban sprawl tended to be ignored as a large context of the implementation of Law No. 41 of 2009 concerning the Protection of Sustainable Food Agriculture Land. Anticipation of the problem of land conversion becomes sectoral, limited to the agricultural sector only, not connected with other policies such as housing and automobile, so that the law fails to be implemented.
\end{abstract}

Keywords: urban sprawl, land conversion.

\section{A. Pendahuluan}

Penjalaran kota (urban sprawl) dalam bentuk pembangunan kota dengan kepadatan rendah atau tersebar tidak teratur adalah masalah besar yang dialami banyak kota di dunia. Beberapa literatur menganggapnya sebagai masalah alamiah yang tak terhindarkan seiring pertumbuhan populasi di suatu wilayah. Sehingga studi yang ada lebih fokus untuk kepentingan mengukur dan memahaminya.

\footnotetext{
" Makalah pada Seminar Nasional "Dinamika Permukiman dan Pembangunan Wilayah di Indonesia" yang diselenggarakan oleh Departemen Geografi Pembangunan, Fakultas Geografi Universitas Gadjah Mada, Yogyakarta, 16 Agustus 2019.
} 
Tetapi belakangan masalah penjalaran kota sudah dianggap masalah besar yang perlu dimitigasi dengan kebijakan.

Glaeser \& Kahn (2004) adalah termasuk di antara kalangan yang berpendapat bahwa urban sprawl adalah hal yang tak terhindarkan. Mereka menyampaikan bahwa sprawl bukanlah hasil dari kebijakan pemerintah yang eksplisit atau perencanaan kota yang buruk, melainkan produk yang tak terhindarkan dari kehidupan berbasis mobil. Saat pada abad ke-21 bentuk dominan dari kehidupan kota didasarkan pada mobil atau kendaraan bermotor, maka menurut mereka sprawl ada di mana-mana dan terus berkembang.

Dampak yang ditimbulkan oleh urban sprawl sesungguhnya sangat serius. Lebih-lebih lagi di negara berkembang. Salah satunya menurut Sudhiraa, et.al. (2004) di negara berkembang seperti India, di mana populasinya lebih dari satu miliar, urban sprawl mengambil korban pada sumber daya alam dengan kecepatan yang mengkhawatirkan.

Bukan saja hanya dengan terjadinya alih fungsi lahan yang mengancam ketersedian pangan, urban sprawl juga membuat permukiman tumbuh tanpa fasilitas dasar yang memadai seperti seperti air, sanitasi dan listrik. Akibatnya, urban sprawl juga berpengaruh terhadap kesehatan masyarakat. Bahkan di Amerika Serikat, di luar dampak emisi karbon terhadap kesehatan, menurut Lopez (2004) ada hubungan antara urban sprawl dan obesitas. Ia menyimpulkan hal itu setelah mengontrol jenis kelamin, usia, ras/etnis, pendapatan, dan pendidikan, untuk setiap kenaikan 1 poin dalam indeks urban sprawl (skala 0-100), risiko kelebihan berat badan meningkat $0,2 \%$ dan risiko obesitas meningkat $0,5 \%$.

Untuk mengantisipasi dampak urban sprawl tersebut, khususnya terhadap alih fungsi lahan, beberapa negara sudah memasang target terukur dalam kebijakannnya. Bovet, Reese \& Köck (2018) telah melakukan penilaian hukum komparatif yang melihat bagaimana tantangan alih fungsi lahan ini ditangani di negara-negara tertentu. Evaluasi menunjukkan Jerman, Swiss, Belanda, Spanyol, dan Polandia telah maju dalam menyesuaikan undang-undang lingkungan dan perencanaan mereka. Hanya dua negara yang telah menetapkan target politik yang jelas: Jerman telah menetapkan target untuk mengurangi pengambilan lahan untuk pemukiman manusia dan infrastruktur transportasi hingga maksimum 30 ha sehari 
dan Swiss telah menetapkan target membatasi konsumsi tanah untuk keperluan perumahan sebesar $400 \mathrm{~m} 2$ per kapita.

Studi yang dilakukan Colsaet, Laurans \& Levrel (2018) memberi kerangka lebih jelas untuk memahami tentang urban sprawl, alih fungsi lahan pertanian dan kebijakan yang perlu diambil oleh pemerintah. Menurut mereka, pengambilan lahan (alih fungsi lahan) dalam arti perubahan transformasi ruang pertanian, alami dan semi-alami menjadi penggunaan perkotaan dan buatan lainnya itu terkait erat dengan urban sprawl (pembangunan kota dengan kepadatan rendah atau tersebar). Untuk itu, mereka menganalisis 193 artikel ilmiah yang diambil melalui metodologi sistematis untuk mengetahui faktor penentu alih fungsi lahan tersebut. Hasilnya bisa diamati dalam gambar berikut.

\section{Gambar 1. Bagan Faktor Penentu Alih Fungsi Lahan}

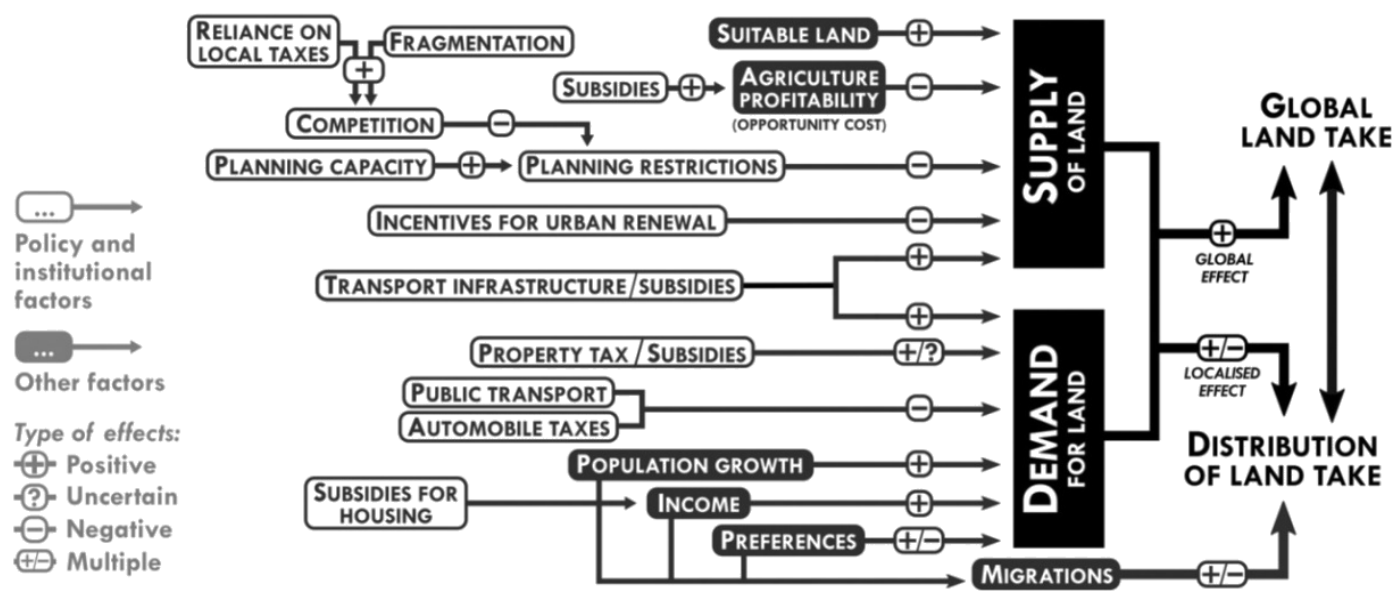

Sumber: Colsaet, A., Laurans, Y, \& Levrel, H. (2018)

Gambar 1. tersebut merangkum identifikasi hubungan sebab akibat antara pengambilan lahan dan berbagai faktor yang mempengaruhinya. Pertumbuhan populasi dan pendapatan, serta pengembangan infrastruktur transportasi dan penggunaan mobil, secara luas ditelaah sebagai faktor yang paling sering ditemukan meningkatkan alih fungsi lahan. Faktor-faktor politik dan institusional secara luas disebutkan dalam literatur yang dipelajari menunjukkan bahwa penyebaran perkotaan bukan hanya hasil dari "kekuatan pasar" tetapi juga dibentuk melalui kebijakan publik. Selain itu, perencanaan yang lemah atau tidak memadai, subsidi untuk konsumsi tanah dan transportasi mobil dikatakan 
meningkatkan urban sprawl, sementara harga infrastruktur dan subsidi untuk pembaruan perkotaan akan memiliki efek sebaliknya. Pengaturan kelembagaan, terutama fragmentasi administratif, ketergantungan pada pajak daerah, dan persaingan antara yurisdiksi lokal, diduga menjadi penentu utama pengambilan tanah atau lahan.

Sekian banyak faktor yang disampaikan oleh oleh Colsaet dkk. tersebut menjelaskan bahwa alih fungsi lahan betul-betul memiliki dimensi yang luas. Lingkup kebijakan terkait alih fungsi lahan ternyata menyangkut berbagai hubungan antar wilayah, antara desa dan kota, juga antara berbagai sektor. Tidak hanya sektor pertanian saja tetapi juga sektor-sektor lain yang saling terkait. Saat Indonesia telah memiliki Undang-Undang Nomor 41 Tahun 2009 tentang Perlindungan Lahan Pertanian Pangan Berkelanjutan, apakah sekian banyak faktor konteks kebijakan yang terkait dengan urban sprawl tersebut telah terbaca dan diantisipasi? Tulisan ini berusaha untuk menjawab pertanyaan tersebut.

\section{B. Urban Sprawl di Indonesia}

Kajian terhadap urban sprawl dan dampaknya sudah cukup banyak dilakukan di Indonesia. Meski menggunakan berbagai pendekatan, tetapi menujukkan bahwa urban sprawl terjadi hampir di semua kota besar di Indonesia. Lebih-lebih lagi di Pulau Jawa. Fisik antar kota-kota hampir menyatu dan mengurangi ketersediaan lahan persawahan dengan massif.

Kajian yang dilakukan Desiyana (2018) menyatakan bahwa urban sprawl mempengaruhi kualitas lingkungan, baik kualitas udara dan air. Penelitiannya menggunakan dua studi kasus dari dua kota di Indonesia yang saling bersebelahan yaitu Depok, Jawa Barat dan DKI Jakarta. Kedua kota mempunyai hubungan erat dalam pembangunan ekonomi, mobilitas masyarakat, elemen alam, perencanaan kota, dan kedua kota tersebut mempunyai populasi terbesar dan wilayah terpadat di Indonesia. Jakarta tumbuh dengan sangat cepat dan menjadi pusat perekonomian, politik, hiburan, pendidikan dan sebagainya dan diikuti oleh Depok. Rencana Depok sebelumnya adalah sebagai daerah penyangga hijau untuk Jakarta, namun Depok telah bertumbuh menjadi kota besar. Kedua kota tersebut 
mempunyai kondisi yang sama, yaktu berkembang cepat tanpa perencanaan dan menciptakan urban sprawl.

Pada wilayah yang lebih luas, mencakup Bogor, Depok, Tangerang dan Bekasi (Bodetabek), penelitian Prasetyo (2017) menemukan bahwa luas wilayah terbangun pada tahun 1989 adalah 5,93 \% dari keseluruhan wilayah Bodetabek. Kemudian pada tahun 2000, luasan wilayah terbangun meningkat $11,99 \%$ dari seluruh wilayah Bodetabek. Luasan tersebut meningkat tajam pada tahun 2014, yaitu $\pm 25,73 \%$ dari keseluruhan luas wilayah Bodetabek.

\section{Gambar 2. Peta Wilayah Terbangun Bodetabek 1989-2014}

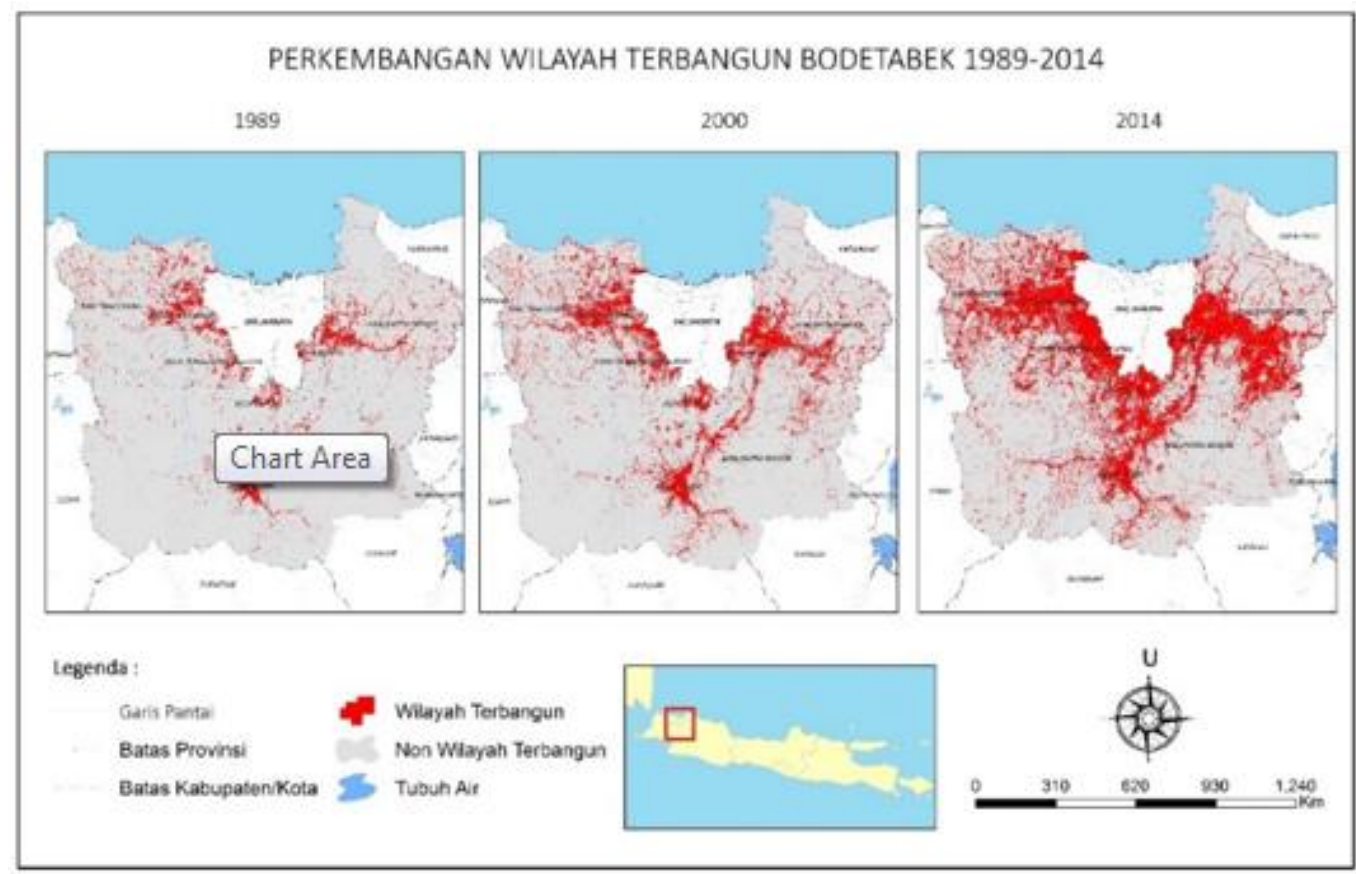

Sumber: Prasetyo (2017)

Giyarsih, S. (2017) juga telah melakukan studi terhadap gejala urban sprawl di Yogyakarta. Penelitiannya menyimpulkan bahwa gejala urban sprawl di daerah pinggiran kota (urban fringe) telah mengakibatkan terjadinya proses konversi lahan pertanian ke non pertanian. Untuk selanjutnya proses konversi lahan pertanian ke non pertanian tersebut mengakibatkan terjadinya proses densifikasi (pemadatan) permukiman di daerah pinggiran kota. Dampak yang ditimbulkannya meliputi sosial ekonomi, kultural dan lingkungan fisik. Ia juga mengutip data yang disampaikan oleh Hadi (2001) bahwa pada rentang tahun 1987-1996 saja (saat kendaraan bermotor hanya dimiliki sedikit penduduk) lahan yang persawahan yang terkonversi sudah mencapai 392 hektar. 
Studi yang dilakukan Aprillia \& Pigawati (2018) di Kota Semarang menjelaskan bahwa pusat kota sebagai pusat kegiatan komersial menyebabkan perkembangan kota bergeser ke pinggiran dengan kepadatan rendah dan terfragmentasi. Entropi Shannon dengan integrasi GIS adalah metode yang efektif untuk mengukur penyebaran perkotaan, karena menggambarkan tingkat area terbangun yang tersebar luas di suatu area. Penelitian ini menunjukkan bahwa pada tahun 2006 dan 2016, urban sprawl di Kota Semarang memiliki tiga jenis tipologi yang dapat digolongkan sebagai tipologi I (tingkat rendah), tipologi II (tingkat menengah) dan tipologi III (tingkat tinggi). Dampak urban sprawl pada tipologi II dan III dapat diminimalisir melalui penyediaan perumahan yang terjangkau dengan infrastruktur yang memadai, dan peningkatan sistem perizinan untuk pembangunan perumahan dan permukiman.

Fenomena yang hampir menyeluruh terjadi di berbagai kota tersebut bisa menjadi salah satu penjelas mengapa konversi lahan pertanian terjadi dengan sangat massif di Indonesia. Harian Kompas pada tanggal 15/9/2014 memberitakan pernyataan Menteri Pertanian Suswono bahwa setiap tahun sekitar 110.000 hektar lahan pertanian produktif beralih fungsi atau terkonversi.

\section{Implementasi Kebijakan Perlindungan Lahan Pertanian Pangan Berkelanjutan}

Pemenuhan hak atas pangan merupakan tugas negara dan terjaminya kebutuhan pangan merupakan hak asasi manusia. Hal tersebut sejalan dengan ketentuan dalam Pasal 28A dan Pasal 28C Undang-Undang Dasar Negara Republik Indonesia Tahun 1945 dan juga sesuai dengan Article 25 Universal Declaration of Human Rights Juncto Article 11 International Covenant on Economic, Social, and Cultural Right (ICESCR). Pemenuhan hak itu tentu tidak bisa dilakukan jika lahan pertanian telah beralih fungsi. Sehingga pada tahun 2009 disahkan Undang-Undang Nomor 41 Tahun 2009 tentang Perlindungan Lahan Pertanian Pangan Berkelanjutan.

Namun setelah sepuluh tahun sejak undang-undang tersebut disahkan, alih fungsi lahan pertanian tetap saja terjadi secara massif. Implementasi kebijakan 
Undang-Undang Nomor 41 Tahun 2009 tentang Perlindungan Lahan Pertanian Pangan Berkelanjutan kemudian dianggap mengalami kegagalan.

Menurut Abidin (2012): "Implementasi suatu kebijakan pada dasarnya merupakan transformasi yang multi organisasi. Oleh karena itu, strategi implementasi mengaitkan berbagai lapisan dan kelompok dalam masyarakat. Semakin banyak kepentingan yang terakomodasikan, semakin besar, semakin besar kemungkinan yang suatu kebijakan berhasil diimplementasikan.” Merilee S. Grindle (1980) juga menyatakan bahwa implementasi adalah proses politik dan proses administratif yang keberhasilannya dipengaruhi oleh dua variabel yang fundamental, yaitu konten atau isi kebijakan (content of policy) dan konteks atau lingkungan implementasi (context of implementation). Ia juga telah merumuskan bagaimana konten dan konteks tersebut saling berhubungan.

Jika mengikuti model yang dibuat oleh Grindle tersebut, maka kesuksesan implementasi ditentukan oleh konten sekaligus konteks kebijakan tersebut. Isi kebijakan yang tidak mengindahkan keterkaitan dengan sektor yang lain atau konteks yang melingkupinya akan mengalami kegagalan implementasi.

Selain isi di dalam undang-undang itu sendiri, UU 41/2009 telah memiliki aturan turunan. Di level pemerintah pusat, peraturan pemerintah (PP) dan peraturan menteri telah terbit sebagai amanah UU tersebut. Peraturan Pemerintah (PP) yang telah terbit antara lain PP No. 1/2011 tentang Penetapan dan alih Fungsi Lahan Pertanian Pangan Berkelanjutan, PP 12/2012 tentang Insentif Perlindungan Lahan Pertanian Pangan Berkelanjutan, PP 25/2012 tentang Sistem Informasi Lahan Pertanian Pangan Berkelanjutan, PP 30/2012 tentang Pembiayaan Perlindungan Lahan Pertanian Pangan Berkelanjutan.

Dari segi dana, berdasarkan pasal 5 PP 30/2012, kegiatan Perlindungan Lahan Pertanian Pangan Berkelanjutan yang dibiayai meliputi: a. perencanaan dan penetapan; b. pengembangan; c. penelitian; d. pemanfaatan; e. pembinaan; f. pengendalian; g. pengawasan; h. sistem informasi; dan i. perlindungan dan pemberdayaan petani. Pasal 26 PP tersebut menjelaskan lebih lanjut tentang pembiayaan kegiatan perlindungan petani sebagaimana dimaksud dalam Pasal 5 huruf i tersebut meliputi pemberian jaminan kepada Petani terhadap: a. harga komoditas pangan pokok yang menguntungkan; b. diperolehnya sarana produksi 
dan prasarana pertanian; c. pemasaran hasil pertanian pangan pokok; d. pengutamaan hasil pertanian pangan dalam negeri untuk memenuhi kebutuhan pangan nasional; dan/atau e. ganti rugi akibat gagal panen.

Selanjutnya pasal 29 PP 30/2102 menjelaskan pembiayaan kegiatan pemberdayaan Petani sebagaimana dimaksud dalam Pasal 5 huruf i meliputi: a. penguatan kelembagaan Petani; b. penyuluhan dan pelatihan untuk peningkatan kualitas sumber daya manusia; c. pemberian fasilitas sumber permodalan; $d$. pemberian bantuan kredit kepemilikan lahan pertanian; e. pembentukan lembaga pembiayaan mikro di bidang pertanian; f. pemberian fasilitas pendidikan dan kesehatan rumah tangga Petani; dan/atau g. pemberian fasilitas untuk mengakses ilmu pengetahuan, teknologi, dan informasi.

Sumber biaya disebut dalam pasal 31 PP 30/2012 yang menyatakan bahwa (1) Sumber Pembiayaan Perlindungan Lahan Pertanian Pangan Berkelanjutan berasal dari APBN, APBD provinsi, dan APBD kabupaten/kota. (2) Pembiayaan Perlindungan Lahan Pertanian Pangan Berkelanjutan selain bersumber sebagaimana dimaksud pada ayat (1) dapat diperoleh dari: a. dana tanggung jawab sosial dan lingkungan dari badan usaha; b. kelompok tani, gabungan kelompok tani, dan/atau masyarakat; c. hibah; dan/atau d. investasi.

Jika dicermati dari rangkaian kebijakan yang telah ada, kebijakankebijakan tersebut belum menyentuh masalah fundamental terkait tanah atau lahan pertanian yang terus beralih fungsi mengikuti mekanisme pasar. Kebijakan mencegah alih fungsi lahan justeru bias dengan kegiatan peningkatan produktivitas pertanian. Saat mekanisme pasar yang ternyata berjalan mengendalikan alih fungsi lahan, maka semestinya pemerintah mengikuti mekanisme pasar tersebut jika ingin mengendalikannya. Jika pemerintah tidak lagi punya kuasa untuk memaksa, maka pemerintah harus mengintervensi pasar dengan membeli tanah-tanah tersebut. Tidak terlihatnya alokasi agar tanah-tanah sawah tersebut menjadi tanah dalam kendali pemerintah (atau bank tanah), menunjukkan secara praktis kebijakan ini tidak mengakomodasi kondisi yang terjadi. Tidak terakomodirnya kondisi tersebut menunjukkan bahwa kebijakan ini belum menyentuh masalah fundamental penyebab terjadinya alih fungsi lahan pertanian. 
Kebijakan yang terlihat agak menyentuh tentang kepemilikan lahan hanya nampak pada PP 30/12 pasal 29 huruf d yang menyatakan adanya pembiayaan untuk pemberian bantuan kredit kepemilikan lahan pertanian. Meskipun belum ada praktek yang lebih nyata terkait ini, namun ada upaya melanjutkan amanat Undang-Undang Pokok Agraria (UUPA) yang memiliki visi lahan untuk petani penggarap. Upaya redistribusi lahan bagi petani tidak bisa hanya melalui upaya membantu pemberian kredit, sebab pada kenyataannya banyak petani (penggarap) yang tidak bisa mengakses kredit perbankan tanpa jaminan tanah.

Adanya jaminan penerbitan sertipikat hak atas tanah pada Lahan Pertanian Pangan Berkelanjutan tidak bisa dikatakan insentif yang realistis bagi petani penggarap yang tidak memiliki lahan. Sehingga pemerintah perlu lebih fokus terhadap lahannya dan harus melakukan intervensi terhadap mekanisme pasar yang berjalan jika kebijakan ini ingin efektif. Lebih dari sekedar memberi insentif yang telah disebut dalam beberapa aturan, pemerintah perlu segera menempuh kebijakan pembentukan bank tanah sebagai salah satu mekanisme "operasi pasar" yang telah berhasil diterapkan oleh banyak negara.

Salah satu konteks yang mempengaruhi alih fungsi lahan adalah peristiwa waris. Ia menjadi sebab penting fragmentasi lahan pertanian dan berujung pada alih fungsi. Krisdyatmiko (2015) menyampaikan bahwa sistem pewarisan semakin mempersempit kepemilikan lahan pertanian, sehingga petani memilih untuk menjualnya. Simatupang dan Irawan (dalam Zakaria dan Rachman, 2013) mengungkapkan bahwa alih fungsi lahan dapat terjadi akibat dorongan penawaran lahan oleh petani, karena adanya penurunan rente usaha pertanian dan penurunan luas pemilikan per rumah tangga tani sebagai akibat fragmentasi lahan yang terkait dengan berlakunya sistem waris pecah-bagi.

Penelitian Wibowo dkk (2015) juga mengungkapkan bahwa faktor penghambat keberhasilan kebijakan perlindungan lahan pertanian pangan berkelanjutan di Kabupaten Temanggung adalah sistem bagi waris di masyarakat Temanggung terhadap lahan waris. Demikian pula Janti, dkk (2016) menyampaikan bahwa tingginya fragmentasi lahan akibat hukum waris adalah salah satu dari 8 (delapan) faktor yang mendorong terjadinya alih fungsi lahan pertanian di Kabupaten Bantul. Penelitian dengan lingkup wilayah lebih luas yang 
dilakukan oleh Bappenas juga memperkuat berbagai penelitian tersebut bahwa ternyata sebelum ataupun sesudah adanya UU No. 41 Tahun 2009, para pemilik lahan pada umumnya memanfaatkan lahan sesuai peruntukannya, baik untuk lahan padi ataupun tanaman pangan lainnya. Namun, pada kondisi tertentu di mana pemilik lahan tidak memiliki modal untuk usaha ataupun hal lainnya, ataupun hak bagi waris bagi keluarganya, maka kondisi pemanfaatan lahan tidak dapat dipertahankan karena setelah beralih kepemilikan akan sangat ditentukan oleh pemilik lahan baru (Rusono dkk, 2015).

Terakomodirnya kepentingan petani dan manfaat yang akan diterima oleh petani dalam kebijakan LP2B ini memang sangat minim. Kepentingannya hanya diakomodir dalam bentuk asuransi, pengembangan infrastruktur pertanian, pembiayaan penelitian dan pengembangan benih dan varietas unggul, kemudahan dalam mengakses informasi dan teknologi; penyediaan sarana dan prasarana produksi pertanian, jaminan penerbitan sertipikat hak atas tanah pada Lahan Pertanian Pangan Berkelanjutan; penghargaan bagi petani berprestasi tinggi (Pasal 5 PP No. 12/2012). Tidak ada upaya yang terlihat untuk membuatnya menjadi lebih sejahtera.

Kebijakan di level pemerintah pusat terkait alih fungsi lahan, salah satunya yang sudah aplikatif adalah izin lokasi. Izin itu adalah izin yang diberikan kepada badan hukum atau perusahaan untuk mendapatkan tanah di satu tempat. Pada lima tahun terakhir, Peraturan tentang izin lokasi telah berubah selama tiga kali. Pertama, pada Tahun 2015 dengan terbitnya Peraturan Menteri Agraria dan Tata Ruang/Kepala Badan Pertanahan Nasional (Permen ATR/BPN) Nomor 5 Tahun 2015. Kedua, pada tahun 2016 dengan terbitnya Permen ATR/BPN Nomor 19 Tahun 2017. Ketiga, Permen ATR/BPN Nomor 14 Tahun 2018

Beberapa hal penting dalam perubahan tersebut adalah semakin mudahnya perusahaan mendapatkan tanah tanpa izin lokasi. Sejak tahun 2017, izin lokasi tidak diperlukan lagi bagi tanah yang diperlukan untuk melaksanakan rencana Penanaman Modal tidak lebih dari $25 \mathrm{Ha}$ (dua puluh lima hektar) untuk usaha pertanian; $10.000 \mathrm{~m} 2$ (sepuluh ribu meter persegi) untuk usaha bukan pertanian; dan $50.000 \mathrm{~m} 2$ (lima puluh ribu meter persegi) untuk pembangunan rumah bagi MBR (masyarakat berpenghasilan rendah). Ketika tidak diperlukan lagi izin lokasi 
maka pertimbangan teknis tidak diperlukan lagi. Sehingga alih fungsi lahan bisa menjadi semakin mudah dengan alasan pembangunan perumahan.

Dalam konteks atau lingkungan kebijakan, saat sawah dialih-fungsikan baik legal maupun tidak, penting juga melihat perspektif lebih luas yang disampaikan oleh Muta'ali (2011) terkait dengan struktur tata ruang wilayah. Ia berpendapat bahwa permukiman merupakan elemen kunci pembentuk struktur tata ruang wilayah. Oleh karena itu perlu dilakukan pengamatan permukiman sebagai satu kesatuan sosial ekonomi. Sebelumnya ia juga mengutip pendekatan integrasi spasial yang dipopulerkan oleh Rondinelli (1983) yang bertujuan untuk mencapai pertumbuhan ekonomi disertai pemerataan (redistrubution of growth) dengan pembentukan instrumen sistem spasial. Meski Rondinelli berpendapat dalam wilayah yang lebih makro, namun pemikiran integrasi spasial ini bisa juga diterapkan untuk pengendalian tata ruang yang lebih detail.

Jika pendekatan integrasi spasial itu dipakai, maka menata atau melindungi tanah pertanian harus berjalan seiring dengan menata perumahan. Bukan sekedar menata saja, tetapi juga menjamin ketersediaannya. Sebab kebutuhan masyarakat atau warga negara atas tanah pada dasarnya hanya terkait dengan dua hal, yaitu pekerjaan dan perumahan. Kalau dua hal itu sama-sama dijamin (karena juga sudah menjadi amanah konstitusi), maka pemerintah akan memiliki potensi untuk dapat mengendalikan alih fungsi lahan pertanian. Pembangunan rumah vertikal dalam skala besar untuk mencegah alih fungsi lahan pertanian di Indonesia sudah tidak terelakkan lagi. Pembangunan itu sulit terlaksana jika hanya menyerahkan kepada masyarakat secara sendiri-sendiri. Sehingga peran pemerintah secara langsung sangat diperlukan.

Studi yang dilakukan Colsaet, Laurans \& Levrel (2018) seperti telah dibahas dalam pendahuluan menjadi relevan untuk menjadi kerangka untuk menilai implementasi kebijakan perlindungan lahan pertanian pangan berkelanjutan. Konteks besar urban sprawl ternyata diabaikan dalam implementasi kebijakan. Padahal alih fungsi lahan betul-betul memiliki dimensi yang luas. Ia terhubung ke sektor lain seperti perumahan, penggunaan kendaraan bermotor (mobil), transportasi publik dan peningkatan kapasitas kota. Sehingga lingkup kebijakan pun ternyata tidak hanya bisa dilokalisir di tingkat wilayah 
administratif dan sektoral saja. Tetapi menyangkut berbagai hubungan antar wilayah, antara desa dan kota, juga antara berbagai sektor. Sehingga kebijakan yang diambil untuk betul-betul mengendalikan alih fungsi ini harus betul-betul komprehensif. Tidak hanya sektor pertanian saja tetapi juga sektor-sektor lain yang saling terkait.

\section{Kesimpulan dan Saran}

1. Urban sprawl cenderung diabaikan sebagai konteks besar implementasi kebijakan Undang-Undang Nomor 41 Tahun 2009 tentang Perlindungan Lahan Pertanian Pangan Berkelanjutan.

2. Antisipasi atas masalah alih fungsi lahan menjadi bersifat sektoral, terbatas dalam sektor pertanian saja, tidak terhubung dengan kebijakan lain seperti penyediaan perumahan dan pembatasan kendaraan bermotor, sehingga undang-undang tersebut gagal diimplementasikan.

3. Pembangunan perumahan vertikal bisa menjadi salah satu bentuk intervensi teknis yang dilakukan pemerintah. Bentuk intervensi itu adalah bagian dari peran strategis bahwa pemerintah harus mengendalikan mekanisme pasar dan membatasi hubungan kepemilikan tanah pribadi baik luasan maupun batas waktunya.

\section{E. Daftar Pustaka}

Abidin, Said Zainal. (2012). Kebijakan Publik. Jakarta: Penerbit Salemba Humanika.

Aprillia, Y., \& Pigawati, B. (2018). Urban Sprawl Typology in Semarang City. Forum Geografi, 32(2), 131-145. doi:https://doi.org/10.23917/forgeo.v32i2.6369

Bovet, J., Reese, M., \& Köck, W. (2018). Taming expansive land use dynamics - Sustainable land use regulation and urban sprawl in a comparative perspective. Land Use Policy, Volume 77, September 2018, p. 837-845. doi: 10.1016/j.landusepol.2017.03.024

Colsaet, A., Laurans, Y, \& Levrel, H. (2018). What drives land take and urban land expansion? A systematic review. Land Use Policy, volume 79, December 2018, p. 339-349. doi: 10.1016/j.landusepol.2018.08.017

Desiyana, I. (2018). Urban Sprawl Dan Dampaknya Pada Kualitas Lingkungan. Ultimart: Jurnal Komunikasi Visual, 9(2),16-24. Doi: 10.31937/ultimart.v9i2.745 
Giyarsih, S. (2017). Gejala Urban Sprawl Sebagai Pemicu Proses Densifikasi Permukiman di Daerah Pinggiran Kota (Urban Fringe Area) Kasus Pinggiran Kota Yogyakarta. Journal of Regional and City Planning, 12(1), 40-45. Retrieved from http://journals.itb.ac.id/index.php/jpwk/article/view/4312

Glaeser, E.L. \& Kahn, M.E. (2004). Chapter 56 - Sprawl and Urban Growth. Handbook of Regional and Urban Economics, Volume 4, 2004, Pages 2481-2527. Doi: https://doi.org/10.1016/S1574-0080(04)80013-0

Hamdi, Muchlis. (2014). Kebijakan Publik: Proses, Analisis dan Parti/sipasi. Bogor: Penerbit Ghalia Indonesia.

Janti, G.I., Martono, E. \& Subejo, S. (2016). Perlindungan Lahan Pertanian Pangan Berkelanjutan Guna Memperkokoh Ketahanan Pangan Wilayah (Studi di Kabupaten Bantul, Daerah Istimewa Yogyakarta). Jurnal Ketahanan Nasional, Vol 22, No 1 (2016). doi: $10.22146 / \mathrm{jkn} .16666$

Jayadinata, J.T. 1999. Tata Guna Tanah dalam Perencanaan Pedesaan, Perkotaan dan Wilayah. Bandung: Penerbit ITB.

Krisdyatmiko. (2015). Dampak Sosial Dan Ekonomi Alih Fungsi Lahan Pertanian Ke Non Pertanian (Studi Kasus Di Desa Sariharjo, Kecamatan Ngaglik, Kabupaten Sleman).Disertasi. Yogyakarta: Universitas Gadjah Mada

Lopez, R. (2004). Urban Sprawl and Risk for Being Overweight or Obese. American Journal of Public Health 94, no. 9 (September 1, 2004): pp. 1574-1579. https://doi.org/10.2105/AJPH.94.9.1574

Muta'ali, L. (2011). Kapita Selekta Pengembangan Wilayah. Yogyakarta: Badan Penerbit Fakultas Geografi (BPFG) Universitas Gadjah Mada.

Prasetyo, A. (2017). Pola Spasial Penjalaran Perkotaan Bodetabek: Studi Aplikasi Model Shannon's Entropy. Jurnal Geografi Gea, 16(2), 144160. doi:http://dx.doi.org/10.17509/gea.v16i2.2439

Rachman, Benny. Dkk. (2013). Economic Incentives And Institutional Aspects Supporting The Implementation Of The Law On Agricultural Land Protection For Food Sustainability. Agro-Socioeconomic Newsletter. Vol. 07 No. 2, June 2013. Bogor: Indonesian Center for Agricultural Socio-Economic and Policy Studies.

Rusono, Nono. dkk. (2015). Evaluasi Implementasi Kebijakan Lahan Pertanian Pangan Berkelanjutan (LP2B). Jakarta: Direktorat Pangan dan Pertanian Kementerian Perencanaan Pembangunan Nasional/Badan Perencanaan Pembangunan Nasional.

Sudhiraa, H.S., Ramachandraa,T.V. \& Jagadish, K.S.(2004). Urban sprawl: metrics, dynamics and modelling using GIS. International Journal of Applied Earth Observation and Geoinformation,Volume 5, Issue 1, February 2004, Pages 29-39. doi: https://doi.org/10.1016/j.jag.2003.08.002

Wibowo, S.P., Widayati, W. \& Astrika, L. (2015). Implementasi Kebijakan Peraturan Daerah Nomor 2 Tahun 2014 tentang Lahan Pertanian Pangan Berkelanjutan dan Lahan Cadangan Pertanian Pangan 
Berkelanjutan di Kabupaten Temanggung. Journal of Politic and Government Studies, Vol 4, No 3. Diperoleh dari https://ejournal3.undip.ac.id/index.php/jpgs/article/view/8857 